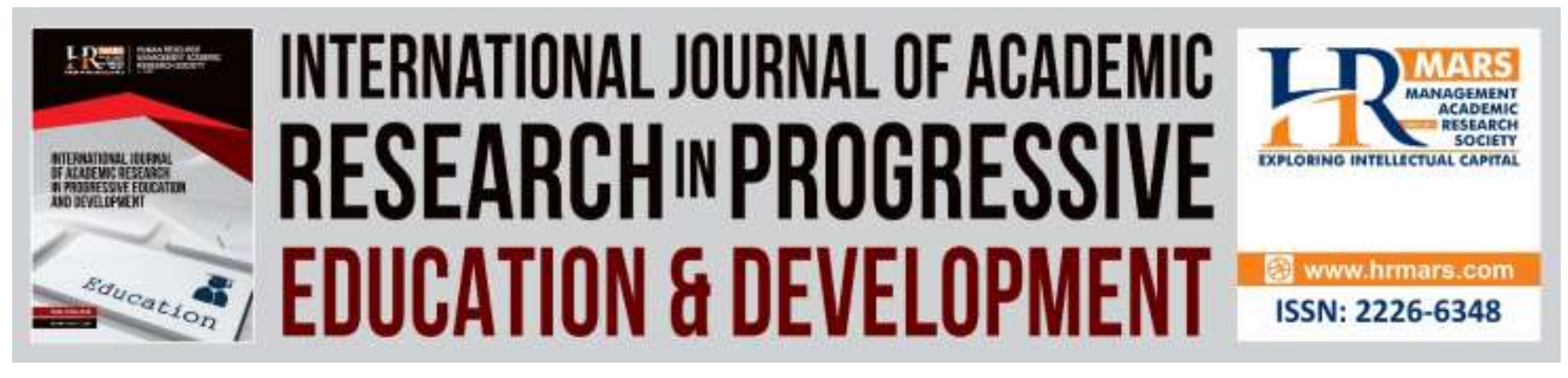

\title{
Relationship between Learning Styles and Research Morale among Iranian Second Grade High School Students
}

\author{
Mariam Shafiei Sarvestani, Fadzilah Abd Rahman, Jafar Jahani, Rohollah \\ Mousavipour
}

To Link this Article: http://dx.doi.org/10.6007/IJARPED/v8-i4/6672

DOI:10.6007/IJARPED/v8-i4/6672

Received: 05 October 2019, Revised: 27 October 2019, Accepted: 01 November 2019

Published Online: 30 November 2019

In-Text Citation: (Sarvestani, Rahman, Jahani, \& Mousavipour, 2019)

To Cite this Article: Sarvestani, M. S., Rahman, F. A., Jahani, J., \& Mousavipour, R. (2019). Relationship between Learning Styles and Research Morale among Iranian Second Grade High School Students. International Journal of Academic Research in Progressive Education and Development, 8(4), 643-661.

Copyright: (C) 2019 The Author(s)

Published by Human Resource Management Academic Research Society (www.hrmars.com)

This article is published under the Creative Commons Attribution (CC BY 4.0) license. Anyone may reproduce, distribute, translate and create derivative works of this article (for both commercial and non-commercial purposes), subject to full attribution to the original publication and authors. The full terms of this license may be seen

at: http://creativecommons.org/licences/by/4.0/legalcode

Vol. 8(4) 2019, Pg. $643-661$

http://hrmars.com/index.php/pages/detail/IJARPED

JOURNAL HOMEPAGE

Full Terms \& Conditions of access and use can be found at http://hrmars.com/index.php/pages/detail/publication-ethics 


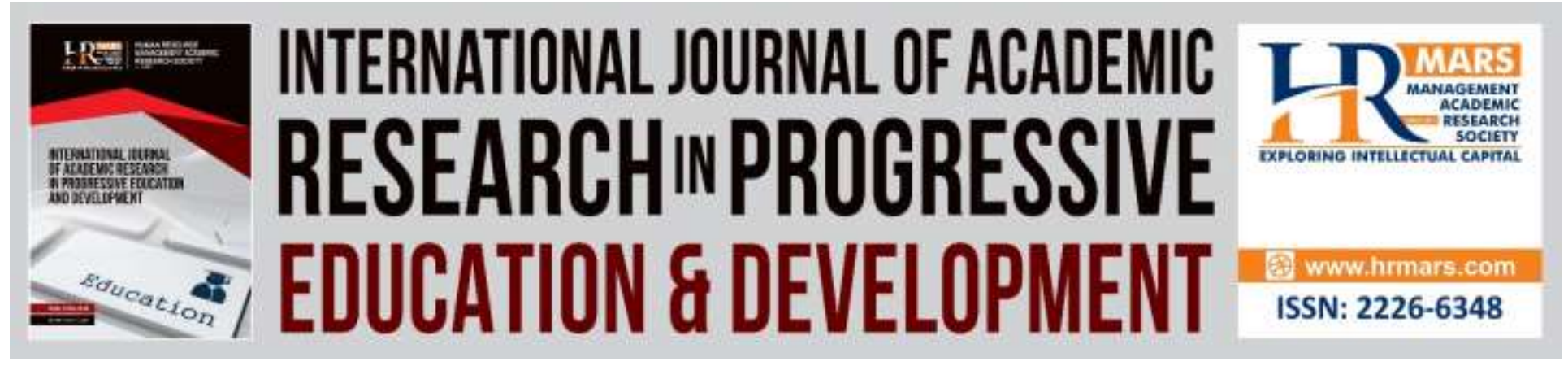

\title{
Relationship between Learning Styles and Research Morale among Iranian Second Grade High School Students
}

\author{
Mariam Shafiei Sarvestani ${ }^{1}$ Fadzilah Abd Rahman*2, Jafar \\ Jahani $^{3}$, Rohollah Mousavipour ${ }^{4}$ \\ 1, 3,4 Faculty of Education and Psychology, Department of Educational Administration and \\ Planning, Shiraz University, Shiraz, Iran. ${ }^{2}$ Faculty of Educational Studies, University Putra \\ Malaysia, Malaysia.
}

\begin{abstract}
Consideration to the learning styles benefits students to participate more enthusiastically in the class activities and to be more confident in answering questions asked by the teacher. This study aimed to investigate the relationship between learning styles and research morale among students of the second grade high school in Shiraz, Iran. Population of the study included all students of the second grade high school in four areas of Shiraz in the academic year of 20152016. A number of 345 students were selected using multi-stage cluster sampling method. Research tools included the Kolb's learning style questionnaire and the research morale questionnaire by Mohammadsharifi (2013). The results were analyzed by SPSS and Lisrel Software's. Results showed that the dominant learning style among the students was a convergent learning style. No difference was seen between research morale of male and female students. Among all learning styles, convergent and divergent styles had a significant association with research morale. Moreover, there was a significant multiple correlations between convergent, divergent, assimilation, and accommodative learning styles and research morale. The finding revealed that the two learning styles of convergent and divergent were stronger predictive of research morale. This study may confirm the role of learning styles in developing research morale and approve the hypothesis that in learning, both convergent and divergent styles should be considered.
\end{abstract}

Keywords: Learning Styles, Research Morale, Convergent Learning Style, Divergent Learning Style, Assimilation Learning Style, Accommodative Learning Style

\section{Introduction}

The human needs learning in order to facilitate responding to the needs and demands of him as well as of the environment. This learning should be in a way that can help the human to influence the environment and his surrounding world. This occurs when the individual has intellectual and 
research morale and explores the issues facing him in the surrounding environment. One of the individual differences affecting the way and the extent of students learning is related to their learning styles. The learning style refers to the fact that how students learn the educational contents and materials. The importance of the learning style as it is considered as one of the essential and key issues concerning the individual differences (Duff, 2004).

Experts and scholars have suggested different and various definitions of learning styles, each of which addressed from a particular perspective. Some scholars in their definition emphasize on the learner's preference and desire, and some others focus on the interaction with others and participation in the learning and teaching process. They are also some experts who stress on the information processing (Emamipour \& Abad, 2007).

Learning styles refer to the methods by which individuals' process the new information in their minds (Seif, 2010). In other words, the personal methods used by an individual for information processing in learning new concepts are called "learning styles" (Largani \& Seif, 2001). Learning styles refer to the fact that in dealing with a situation to what an individual pays attention and for how much and how long. (Entwistle \& Peterson, 2004; Elahi, Azad-Fallah, \& Rasoul-Zade Tabataba'i, 2004; Kolb \& Kolb, 2005; Kozhevnikov, 2007). Learning styles also refer to the quality and desirability of individual learning (Seif, 2010). From the perspective of Kolb (1984), learning styles refer to the beliefs, priorities and behaviors that individuals apply in a certain situation in order to facilitate their learning. Some psychologists and educational experts apply the term "learning preference" instead of learning styles. Woolfolk (2004) who used the term "learning preference" believes in methods that the individuals prefer for studying and learning including "working alone or in group", "listening instead of studying" and "skimming versus speed reading", etc.

Discovering and identifying the learning styles of students makes the teacher to select the methods for teaching that lead students to learn the educational content and materials easier, faster and better. When the teacher pays attention to the learning styles of students, she/he can communicate with students more effectively. This familiarization and communication helps the teacher to become aware of students' knowledge about the lesson content and their learning abilities (Gol \& Javan, 2014).

Learning experts have introduced and classified various learning styles. Kolb's classification of learning styles is considered as one of the most famous and common classification of learning styles. Kolb assumes four methods for learning styles including "concrete experience" (doing/having an experience), reflective observation (reviewing/reflecting on the experience), abstract conceptualization (concluding/learning from the experience) and active experimentation (planning/trying out what that has been learned). These are known as "the experiential learning cycle". Therefore, Kolb has introduced two dimensions and four learning methods. The first dimension includes the concrete experience versus abstract conceptualization, and the second dimension consists of active experimentation versus reflective observation. When these aspects are combined together, the convergent, divergent, assimilation, and accommodative learning 
styles are formed (Hainer et al., 1990).

The ability of individuals in learning styles is different from each other. Divergent learning style is formed by combining two methods of concrete experience and reflective observation. Individuals with this learning style have the ability of imagination, production of diverse and complex theories, observing issues from different perspective and insight. In general, those who benefit from divergent learning style are creative and have high social relationships and art background (Zanich, 1991).

Convergent learning style consists of abstract conceptualization and active experimentation. People with convergent learning style have the ability of finding practical use for ideas and theories and solving problems. These individuals use hypothesis - deductive reasoning and prefer technical issues and working with tools and instruments to social relationships and interactions. Generally, manipulation of objects, logical analysis of opinions, planning, and learning through thinking are the obvious characteristics of these individuals (Anderson \& Adams, 1992). Individuals with convergent learning style are more successful in specialized tasks and technology (Seif, 2010).

Assimilation learning style is formed by combining two methods of abstract conceptualization and reflective observation. Individuals with this learning style are interested in theorization and production of knowledge. They are superior in combining different ideas, inductive reasoning and viewing in a global context than the others. These individuals have a great tendency in thinking about the concepts. This style is relatively the characteristic of basic science and mathematics (Gheibi et al., 2012).

Accommodative learning style is formed by combining two methods of active experimentation and concrete experience. Those who have accommodative learning style, usually learn through emotions, intuition and action. They are interested in acquiring new experience and enjoy from implementing plans and engaging in challenging actions (Seif, 2010). These individuals are more successful in marketing and salesman ship (Seif, 2010).

\section{Problem Statement}

Nowadays, one of the aspirations of the countries is the growth of inventive, creative and researcher individuals who are able to meet their individual needs and help the society to achieve the collective requirements (Mehrinejad, 2005). The education is one of the ways to achieve this goal. Therefore, one of the education's aims is to train individuals who have the ability of doing new tasks (Fisher, 2001). In this regard, fostering the research morale is paid attention as an important matter.

Research skill is considered as the knowledge and art of questioning and answering that requires observation and measurements, theorization, interpretation, modelling and model testing. This depends on experiencing, reflecting and realizing the strengths and weaknesses of its particular methods (Ghasemipour, 2010). From the perspective of John W. Best, research refers to the fact that an individual is able to use appropriate scientific methods in solving problems and finding 
the best respond (Delavar, 2006). In general, the research morale is identified by factors including curiosity, persistence in solving problem, sensitivity to the environment, creative and critical thinking, imagination, problem-solving, teamwork, confidence and self-regulation.

Attention to research morale of students and fostering it can cause students to become familiar with research and its processes. Hence, the effective education should train students as researchers who examine, analyze and interpret the information and try to change the knowledge. What was said previously indicates the importance of learning styles and research morale in improving the education of today's generation. It is, therefore, important to investigate these two issues as well as the relationship between them. Several researches have been conducted on student's learning styles, and few studies are available on research morale. Although, there are studies on areas including learning style and problem solving, learning style and critical thinking, learning style and creativity, and learning style and investigating, the relationship between learning styles and research morale has yet been studied.

\section{Literature Review}

Parsayi and colleagues (2013) compared the cognitive learning styles of conservatory and high school students. The statistical samples of their study consisted of 170 male and female students. Findings revealed that learning styles of high school students more tended to be divergent and learning styles of conservatory students more tended to be accommodative.

Results of the study conducted by Rashidi Jahan and colleagues (2013) indicated that the dominant learning style used by students at University of Medical Sciences was more likely divergent. Khandaghi and Rajaei (2013) studied the effect of student's learning style on their preferred teaching style. Results showed that the university students used convergent and assimilation learning styles. In another study conducted by Ala and colleagues (2013) on the students and faculty members of Tehran University of Medical Sciences, the convergent learning style was considered as the dominant style among the students and faculty members. Moreover, results of the study conducted by Adesunloye et al. (2008) on faculty members of Medicine revealed that the dominant learning style of faculty members was the assimilation style. In another study done by Mitchell \& Nyland (2005) the dominant learning style of faculty members were the assimilation and convergent styles.

In 2012, D'Amore and colleagues investigated the dominant learning style among Nursing and Midwifery students. Results showed divergent style as the dominant learning style of the students. Zoghi et al. (2010) identified the convergent learning style as the preferred learning style among the medical students. Similarly, there are a number of studies conducted on research morale. Mokhtari et al. (2014) investigated the utilization level of research, thinking and communication skills among the fifth-grade students at elementary school in Tehran. In this study, 285 students were examined. Results showed that male and female students had an average score for interpersonal communication skills, critical thinking, creative thinking and research skills. 
In addition, results of Mirsoleimani's research (2011) revealed that the mean score of research among high school students in basic and experimental sciences were higher than the average. In addition, the mean scores of research in male participants were higher than in female. Conversely, findings obtained from the study of Rezaei et al. (2008) showed a significant difference in motivation to study and research between female and male students. Females had higher motivation than males.

Bishop and Bieschke (1998) suggested that variables of expectations for research efficiency, research individual self-efficacy beliefs, research interests, art interests and age, play important roles in predicting the interest to research. Moreover, Mao and Chang (1998) in a research conducted on the effect of the research based teaching method on learning of science concepts to high school students; found that the research based teaching method had a significant role on learning of science concepts to students.

Another research was conducted by Mokhtari et al. (2014) to assess the utilization level of communication, thinking and research skills among the students. Results showed that the interpersonal communication skills, creative thinking, creative and critical thinking, and research morale were moderate in male and female students. In addition, Miri (2013) in a similar study found a significant difference on research morale between female and male students so that the mean scores of the research morale for female students was higher than that for male students.

Critical thinking is defined as one of the research morale factors. A number of studies have examined the relationship between critical thinking and learning style. Gyeong and Myung (2008) investigated the relationship between learning styles and critical thinking among the university students in Korea. Findings demonstrated that students with convergent learning style had more tendencies to critical thinking than students with other learning styles.

Guven and Kurum (2008) studied the relationship between learning styles and tendency toward critical thinking among the students of teacher training centers. Results indicated that students with convergent learning style had more curiosity compared to their peers with divergent learning style. In addition, students with convergent learning style had more self-confidence compared to those with divergent and accommodative learning styles. Similarly, Wessel and Williams (2004) reported that individuals with convergent learning style had more tendencies to critical thinking.

Creativity is another factor for research morale. There are several studies concerning the relationship between creativity and learning styles. Behrouzi et al. (2013) conducted a study comparing the high school students with diverse learning styles in terms of creativity and learning strategies in Dehdash, Iran. The results showed that students with divergent learning style had more creativity than those with convergent, assimilation and accommodative learning styles. Demirbas and Demirkan (2007) compared individuals with convergent and divergent learning styles in terms of the creativity. They suggested that individuals with divergent learning style had more creativity compared to those with convergent learning styles. Dermitzaki et al. (2009) showed that students with divergent learning style had more creativity and preference to apply 
different methods and approaches.

"Problem solving" is defined as another factor of research morale. There are a number of researches that deal with the relationship between problem solving and learning style. Uchenna and Sunday (2011) studied the teachers' problem solving abilities, students' learning styles and their academic success in Biology. Results indicated that teachers with problem solving ability were able to change their teaching styles and pay attention to the students' learning styles. Consequently, this leaded to success and progress of students in Biology. Sunday et al. (2013) in a similar study examined the teachers' problem solving abilities, as well as students' learning styles and their academic success in Physics. Findings indicated a significant positive correlation between the teachers' problem solving skill and students' learning styles.

Yogaraj and Selvaraju (2014) examined the effect of metacognition and learning styles on problem solving abilities. The researchers concluded that metacognition and learning styles had positive effects on problem solving abilities. Moreover, Direito et al. (2012) found that individuals' problem solving ability depends on their different learning styles. In other words, different learning styles have an impact on learner's methods and approaches in problem solving (Felder and Silverman, 1988).

\section{Research Questions}

Research questions in this study are

1.3.1 What is the dominant learning style among the second grade high school students?

1.3.2 To what extent do they have research morale?

1.3.3 Is there a significant difference between the research morale of male and female students?

1.3.4 Is there a significant correlation between different types of learning styles and research morale among the second grade high school students?

1.3.5 Can learning styles be considered as a significant predicator for research morale among the second grade high school students?

\section{Methodology}

\section{Population and Sampling}

The statistical population of the current study included all the second grade high school students in Shiraz, Iran consisting of 29980 students who were studying in the academic year of 2015 2016. The sample size in the study included 345 male and female students in Shiraz. Samples were chosen from four male and four female high schools, randomly selected from each region of the city using the multi-stage cluster sampling method.

\section{Measuring Tool}

The questionnaire used in this study was developed by David Kolb (1976) to assess individual learning styles and revised in 1984. The revised version of Kolb's questionnaire was used in the study. Kolb's learning style inventory is a 12-item questionnaire in which each question consists of four options indicating four learning styles: concrete experience, reflective observation, 
abstract conceptualization and active experimentation. Answers are based on the participants' preferences of their learning methods and scores range from 1 to 4 . If the participant's learning method has full consistency with the proposed options, the score is 4 . If the consistency is to some extent, the score is 3 . In case of little consistency, the score is 2 and if there is no consistency, the score is 1 . The learning style is then gained by summing these scores.

Two scores are obtained by subtracting scores for abstract conceptualization and concrete experience as well as subtracting scores for active experimentation and reflective observation. These two scores are placed on the vertical axis (CE-AC) and the horizontal axis (AE-RO) on the coordinate table. Kolb (1984) conducted a research on male and female students of the second year. He found that this questionnaire had a good validity and was a useful tool for identifying students' learning styles and methods. In addition, he obtained the reliability of the questionnaire by Cronbach's alpha test and reported the reliability for active experimentation, abstract conceptualization, reflective observation and concrete experience as $0.87,0.83,0.73$, and 0.82 , respectively. In Iran the reliability for Kolb's learning style questionnaire was measured by Hosseini Largani and Seif (2001) using Cronbach's alpha. He reported 0.68, 0.68, 0.77 and 0.76, as reliability of the questionnaire as for concrete experience, reflective observation, abstract conceptualization, and active experimentation, respectively. The reliability of this questionnaire was also measured in this study based on internal consistency. Values included 0.76, 0.67, 0.73, and 0.82 for convergent style, divergent style, assimilation style, and accommodative style, respectively.

\section{Research Morale Questionnaire}

This questionnaire was developed by Mohammadsharifi (2013). The researcher studied factors of research morale by interviewing a number of faculty members and experts. After collecting data through interviewing, the researcher formed a survey questionnaire. 12 faculty members from educational sciences and psychology courses reported the importance of each factor according to the scores ranging from 0 to 10. Accordingly, the preliminary questionnaire with 49 questions with a 4 point scale answers was developed. The questions were developed based on nine effective factors including creative behaviors, critical thinking and problem solving, teamwork ability, continuous effort and diligence, curiosity and questioning, sensitivity to the environment, self-confidence, self-regulation, imagination and spatial perception.

After developing the preliminary questionnaire, the tool were applied and implemented on 56 students similar to the statistical population of the study, and then validity and reliability of the tool were assessed. The reliability of this questionnaire was calculated using Cronbach's alpha coefficient as 0.91 . In addition, to assess the content validity of the questionnaire, this tool was presented to 11 experts in educational sciences and ultimately the final form of the questionnaire was revised in 43 questions. Similarly, in the current study, the reliability of this questionnaire was measured as 0.91 using Cronbach's alpha coefficient.

\section{Results}

The age of the sample group ranged 15 to 18 with a mean of 16.36 years old. The population of 
Vol. 8, No. 4, 2019, E-ISSN: 2226-6348 @ 2019 HRMARS

male and female students included $57.7 \%$ (199 participants) and 42.3\% (146 participants), respectively. $64.6 \%$ of the students studied at the second year, $24.9 \%$ at the third year and $10.4 \%$ at the fourth year of second grade high school.

As it can be seen in Table 1, the mean and standard deviation of the research variables were 119.63 and 11.93 for research morale, 56.97 and 5.41 for divergent style, 63.17 and 5.48 for convergent style, 62.87 and 6.73 for assimilation style and 57.01 and 6.02 for accommodative atyle, respectively. According to this table, convergent learning style had the highest mean score (63.17) and divergent learning style had the lowest mean score (56.97) among the students in four regions of the city. Based on factor $F(70.163)$, there was a significant difference on the students' learning styles in degrees of freedom 3 and 342.

\begin{tabular}{|c|c|c|c|c|}
\hline Patistical inderes & Mean & $\begin{array}{l}\text { Standand } \\
\text { deriation }\end{array}$ & $\begin{array}{l}\text { Yisind } \\
\text { score }\end{array}$ & Meximen score \\
\hline \multicolumn{5}{|l|}{ Variables } \\
\hline Reseachnorale & 119.63 & 11.93 & 85 & 132 \\
\hline Dirergent & 36.97 & 5.41 & 13 & $\pi$ \\
\hline Comrergent & 6317 & 2.45 & 2 & $\pi$ \\
\hline Axsinition & 685 & 6.37 & 27 & 3 \\
\hline Acresemodative & 3701 & 602 & 2 & 76 \\
\hline
\end{tabular}

According to the information given in Table 2, there is a significant association between different types of learning styles and research morale among the students of second grade high school.

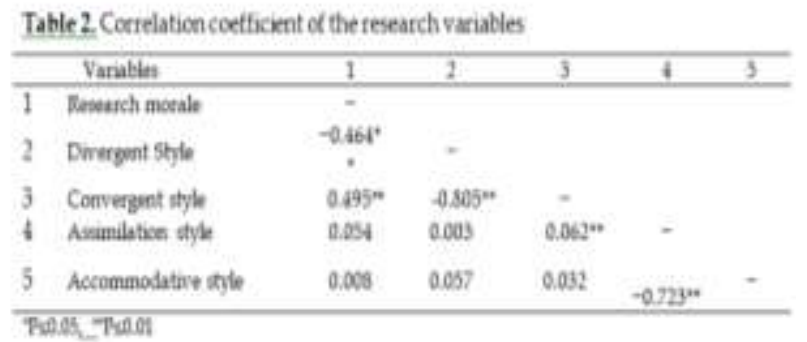

The variables in Table 2 indicate that the correlation coefficient obtained from the correlation between convergent and divergent variables and research morale was significant at level of $p<0.01$. However, there was no significant association between assimilation and accommodative variables, and research morale. The significance levels for correlation coefficients are shown in Table 2 with * for $\mathrm{P} \leq 0.05$ and ** for $\mathrm{P} \leq 0.01$.

Results summarized in Table 3 show significant multiple correlations between convergent, divergent, assimilation, and accommodative learning styles and research morale. In order to assess the multiple correlations between learning styles and research morale, multiple regression analysis method was used, simultaneously. 
Vol. 8, No. 4, 2019, E-ISSN: 2226-6348@ 2019 HRMARS

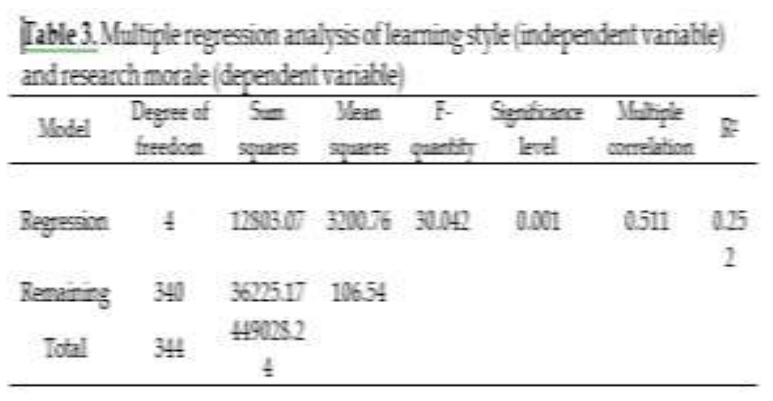

According to the information in Table 3, the multiple correlation coefficient for linear combination of variables of divergent, convergent, assimilation and accommodative learning style with research morale is significant at the level of $p<0.01$. In addition, the variance of $25.1 \%$ related to the research morale can be determined using the variables mentioned above.

\begin{tabular}{|c|c|c|c|c|c|}
\hline $\begin{array}{l}\text { Indeves } \\
\text { Tariables }\end{array}$ & $\begin{array}{l}\text { BNon- } \\
\text { Standard }\end{array}$ & $\begin{array}{l}\text { Standard } \\
\text { Error }\end{array}$ & $\begin{array}{l}\text { Beta } \\
\text { Standard }\end{array}$ & T-Vahe & $\begin{array}{l}\text { Significance } \\
\text { lerel }\end{array}$ \\
\hline (Constant) & 84.94 & 21.37 & & 3.97 & 0,001 \\
\hline Divergent & -0.478 & 0.182 & -0.217 & -2.62 & 0,009 \\
\hline Conrergent & 0.681 & 0.181 & 0.313 & 3.76 & 0001 \\
\hline Assiniatarn & 0.167 & 0.133 & 0.059 & 1.25 & 0.210 \\
\hline Accommodation & 0.147 & 0.141 & 0.074 & 1.04 & 0.297 \\
\hline
\end{tabular}

According to Table 4, the convergent learning styles with beta coefficient of $\beta=0.313$ and the divergent learning style with beta coefficient of $\beta=-0.217$ are stronger predicators for research morale.

In addition to the results mentioned above, based on the Bonferroni post-hoc test results, there were significant differences between convergent and divergent, divergent and assimilation, accommodative and convergent and also between assimilation and accommodative learning styles (Table 5).

\begin{tabular}{|c|c|c|c|c|}
\hline Loxming styles & $\begin{array}{l}\text { Drvergent } \\
\text { Style }\end{array}$ & $\begin{array}{l}\text { Cotwergent } \\
\text { Style }\end{array}$ & $\begin{array}{l}\text { Ansimilation } \\
\text { Style }\end{array}$ & $\begin{array}{l}\text { Accoemmodx: } \\
\text { ve ityle }\end{array}$ \\
\hline \multicolumn{5}{|l|}{ Dovergrat style } \\
\hline Cenvergent shyt & 0.001 & & & \\
\hline Assimilaticestyle & 0.001 & NS & & \\
\hline $\begin{array}{l}\text { Acconimodutive } \\
\text { style }\end{array}$ & NS & 0.001 & 0.001 & \\
\hline
\end{tabular}

Moreover, as the results of one-sample t-test indicate (presented in Table 6), t-value of 18.875 with the significance level of 0.001 confirms the research hypothesis (mean value considered: 86). Given the fact that the significance level is less than the error level of 0.01 , it can be said that the students' research morale with confidence level of 0.99 is higher than the mean score. In addition, the mean score of research morale for female and male students was 119.6 which obviously are higher than the considered mean score. 
INTERNATIONAL JOURNAL OF ACADEMIC RESEARCH IN PROGRESSIVE EDUCATION AND DEVELOPMENT

Vol. 8, No. 4, 2019, E-ISSN: 2226-6348 @ 2019 HRMARS

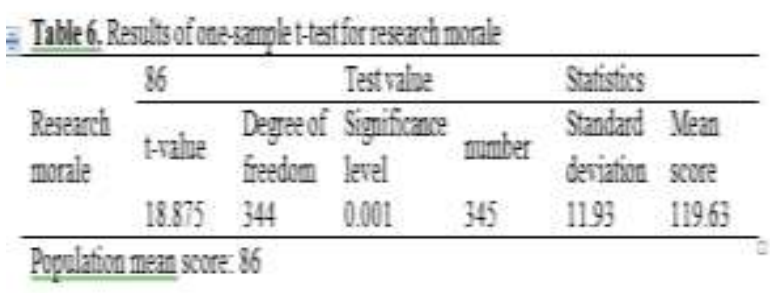

Table 7 illustrates the differences of research morale between male and female students. In order to evaluate this, the variables of gender (in divalent) and research morale were intervallic ally measured.

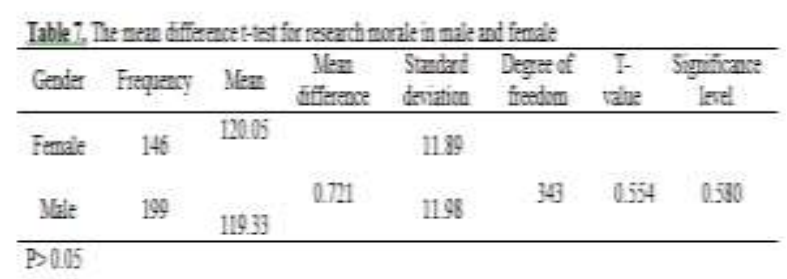

The most appropriate test for comparing these two variables was independent t-test with two independent samples that was used to examine the mean score difference for research morale among male and female students. No significant difference was seen between the variables of gender and research morale (Sig=0.580).

\section{Discussion}

One of the objectives in this study was to examine the students' dominant learning style. Results obtained from the study revealed that the dominant learning style among the students were the convergent learning style which is formed by combining two learning methods of abstract conceptualization and active experimentation. Accordingly, those whose dominant learning style is convergent, are more willing to use logic and thinking to understand the problems and less benefit from their feeling (Khandaghi and Rajaei, 2013). Results of the present study are consistent with those of Ahmadi and Allami (2014); Ala et al. (2013); Khandaghi and Rajaei (2013); Farmanbar et al. (2012); Papzan et al. (2011); Zoghi et al. (2010); Pour-Atashi et al. (2009) and Mitchell and Nyland (2005). However, results are inconsistent with those of Ghiyasi (2014); Parsayi et al. (2013) Rashidi Jahan et al. (2013), D'Amore et al. (2012) and Adesunloye et al. (2008). Since the convergent learning style is considered as the dominant learning style, it seems that the educational system attempts to train individuals who are able to help themselves and the society with their individual abilities in time of difficulties. In addition, one of the goals of the education system is to grow efficient and entrepreneur manpower who are purposefully able to create occupation by acquiring necessary skills according to the needs of the society. Therefore, attention to the convergent learning style can be in line with these goals.

Another objective of the study was to examine the students' research morale. The results of the current study revealed that research morale of students was higher than the average. As more research morale leads to the fact that students feel more willingness to attempt for learning, if the outputs of the education system are developed in line with research morale and critical 
thinking, it will play a significant role in the development of the country (Motlagh and Charkhchi, 2008). Results of this study were also in line with those of Mohammadsharifi (2013) and Mirsoleimani (2011). However, the results were inconsistent with those of the research conducted by Mokhtari et al. (2014). In order to explain these, it can be said that improving the quality of education and changing the traditional education system to the modern one has led to developing new and innovative methods based on the individual and social needs of the students. Student - centered approach and application of new teaching methods is very important in high school, since students are being prepared for their professional life in the future. On the other hand, attention to the students' abilities including self-regulation, confidence, imagination, critical thinking, creative thinking and curiosity can cause the improvement of the research morale in students.

Gender is considered as one of the most important factors in developing research morale in students. Therefore, one of the objectives of the present study was to assess the difference of research morale between male and female students. Findings showed no significant difference between the variables of "gender" and "research morale" in this study. These results are contrary to those obtained from the study of Rezaei et al. (2008); Mirsoleimani (2011) and Miri (2013). In explaining the reason for "no significant difference in research morale between male and female students" in this study compared to the other studies, it can be said that justice is among the values that all human societies are seeking to realize it. Educational justice in the present era has improved due to the importance of training new generation for the development, progress and survival of communities. Accordingly, the factor "gender" or "gender justice" is now one of the major issues and essential challenges of the educational systems in the world. UNESCO in the Education for All (EFA) program and the Dakar Framework for Action document (Peppler Barry, 2000) has considered the gender equality as one of the main goals for the EFA program (Zohrehvand, 2006).

Establishment of gender justice and its implementation in the educational programs has caused male and female students to have a balanced growth. This has led to that the educational content and curriculums are designed in accordance with the interest and desires of both genders and any form of discrimination in the educational programs is avoided.

On the other hand, the gender role has faded away in today's world and girls alongside with boys are seeking to get independent (Mahbod, 2011). Furthermore, nowadays families are not paid much difference for their children's training and the stereotypical roles are not imposed on them anymore (ibid). In addition, the need of society to change and progress in the global arena made the education system to generate and develop contents that can lead to develop science and research among the individuals of the society. Moreover, they can provide equal educational opportunity to individuals in the society regardless of their gender, so that they can develop their talents and capabilities.

Investigating the relationship between learning styles and research morale in this study showed a significant correlation between different types of learning styles and research morale among 
the students. In other words, there was a significant positive correlation between the convergent learning style and research morale. It means the increased use of convergent learning style can increase the level of research morale among the students. The other finding obtained from the study suggests that there is a significant negative correlation between divergent learning style and research morale. It means that the increased use of divergent learning style has a negative impact on the level of students' research morale.

Although studies that examine the relationship between learning style and research morale have not yet been conducted, several research investigated the relationship between learning style and the research morale factors including critical thinking, problem solving and creativity. Few studies have been conducted on learning styles and critical thinking. The results obtained from this study are in line with those gained by Nouhi et al. (2014); Ghadampour, et al. (2013); Nasr Abadi et al. (2013); Guven and Kurum (2008); Gyeong and Myung (2008); Suliman (2006); Wessel and Williams (2004) and Johnson (2002). In addition, the results of the study are inconsistent with those of Myers and Dyer (2006) and Rudd et al. (2000).

In explaining these findings, it can be said that the convergent learning style consists of two learning methods of abstract conceptualization and active experimentation. The strengths of the convergent learning style include problem solving, efficient decision making, operational and objective use of opinions and ideas, note-taking and deep analytical understanding of the subject of learning and ultimately applying hypothesis - deductive reasoning (Emamipour and Abad, 2007). These factors are consistent more with critical thinking that is in line with problem solving whose characteristics are reasoning, inference, good recognition, organized thinking, and logical interpretation and evaluation (Abadi et al., 2013).

Those who use convergent learning style prefer to be in the position of a problem and try different ways to find a solution for their problems. These individuals have a high risk appetite and the ability to have a great influence and impact on others (Kolb and Kolb, 2005). Suliman (2006) believes that these individuals have critical thinking tendencies including truth-seeking, analysis, systematic methods, self-confidence, and cognitive maturity. On the other hand, the interest in curiosity, investigation, and critical thinking along with confidence and cognitive abilities such as reviewing the validity of resources and selecting the most relevant information lead these people to benefit more from critical thinking (ibid). It is, therefore, obvious that individuals with convergent learning style have high tendency toward critical thinking.

Some studies have been conducted on the creativity as one of the research morale factors and learning styles. The results of the present study are inconsistent with those of Behrouzi et al. (2013); Dermitzaki et al. (2009) and Demirbas and Demirkan (2007). Creativity is considered as one of the nine factors for research morale. Although, having the characteristics of creative thinking is necessary for research morale, it is not sufficient.

Problem solving is one of the other factors for research morale. Several studies have been conducted concerning the relationship between problem solving and learning styles. Results of the current study are in line with those of Yogaraj and Selvaraju (2014); Sunday et al. (2013); 
Direito et al. (2012); Uchenna and Sunday (2011); Akbari and Motamedi (2011), Weber (2005); Ross (2003); and Lithner (2003).

Those who enjoy convergent learning styles have the ability of problem solving and decision making based on the solutions they find (Seif, 2010). In addition, these individuals try to immediately adopt the appropriate solution when they are faced with problems or focus their efforts on a single solution to achieve the appropriate answer. Those with convergent learning style have better performance in problem solving and structural design (Suleimannejad and Hosseininasab, 2012). Hill (1998) believes that these individuals have high abilities in organizing information, designing experiments and analyzing data, creating new ways of thinking and choosing the best goal. Therefore, it can be said that convergent learning style has a positive and significant correlation with the ability of problem solving as one of the factors of research morale.

One more objective of the present study was to investigate whether the students' learning style can be a significant predicator for students' research morale. The results of this study suggested that the convergent learning style may be a predicator for research morale among the students. In other words, individuals with convergent learning style can also have research morale. However, there is no study that can confirm or reject the above findings.

\section{Conclusion}

In conclusion, it can be said that the individuals with convergent learning style are able to find the ways and solutions for practical use of theories and problems by enjoying the ability of reasoning and judgment. In other words, an individual with such learning style can solve problems and make decisions based on the solutions found. These individuals receive the information in the abstract terms and process them actively. Those with convergent learning style pay attention to the utility, productivity and efficiency of the issues. They learn through using and testing the information and following a certain method, they are usually serious in doing their affairs, and prefer to work on their own.

On the other hand, in order to explain the predictive power of research morale by convergent learning style, the characteristics of those who are researchers can be pointed out. Researchers do study and examine the possible ways and methods in order to deal with possible challenges and problems by enjoying logical thinking and critical approach. The perspective of these individuals toward the knowledge is temporary. Therefore, they try to provide new methods to produce and develop the knowledge. Researchers believe that there is no end for research. Consequently, these individuals with critical attitude and correct judgment try to acquire recognition, understand the science, and logically explore and investigate the researches. As De boo (2004) believes, the researchers have characteristics such as curiosity, broad-mindedness, critical and creative thinking, effort and perseverance, and interaction and cooperation. It is, therefore, obvious that the individuals with convergent learning style have research morale.

\section{Corresponding Author}

Fadzilah Abd Rahman (PhD) is a senior lecturer at the Faculty of Educational Studies, University 
Vol. 8, No. 4, 2019, E-ISSN: 2226-6348 @ 2019 HRMARS

Putra Malaysia, Malaysia. Email: dzila@upm.edu.my

\section{References}

Adesunloye, A., Aladesanmi, O., Henriques, M., and Ivonye, C. (2008), "The preferred learning style among residents and faculty members of an internal medicine residency program", Journal of the National Medical Association, Vol. 100 No. 2, pp. 172-175.

Ahmadi, M., and Allami, A. (2014), "A comparative study on health workers' learning styles using Kolb and Vark's questionnaires and its relations with academic success", Research in Medical Education, Vol. 1 No. 6, pp. 18-27.

Akbari, M., and Motamedi, A. (2011), "The relationship between learning style, personality traits, and problem-solving styles", Innovation In Management Education (Journal Of Modern Thoughts In Education, Vol. 3 No. 23, pp. 11-25.

Ala, M., Mirzadeh, A., Gharib, M., and Patricia, H. (2013), "A study on students' learning styles and faculty members in pre-clinical period of general medicine at Tehran University of Medical Sciences", Journal of Medical Education, Vol. 6 No. 10, pp. 10-12.

Anderson, J., and Adams, M. (1992), "Acknowledging the learning styles of divers student population: implication for instructional design", New Direction for Teaching and Learning, Vol. 49, pp. 19-33.

Behrouzi, N., Nasab, P. M. and Yeylagh, S. M. (2013), "A comparative study between male high school students in Dehdasht city and different learning styles in terms of creativity and self-regulated learning strategies", Journal of Teaching and Learning preceding studies, Vol. 20 No. 3, pp. 19-34.

Bishop, R. M. and Bieschke, K. J. (1998), "Applying social cognitive theory to interest in research among counseling psychology students: a path analysis", Journal of Counseling Psychology, Vol. 45 No. 2, pp. 182-188.

D'Amore, A., James, S., and Mitchell, E. (2012), "Learning styles of first-year undergraduate nursing and midwifery students: a cross-sectional survey utilizing the Kolb learning style inventory", Nurse Education Today, Vol. 32 No. 5, pp. 506-515.

De boo, M. (2004), Enquiring Children: Challenging Teaching, (F. Hashemi, Trans), Mashhad: Beh Nashr Publication.

Delavar, A. (2006), Research methodology in psychology and educational sciences, Tehran: Virayesh Publication.

Demirbas, O., and Demirkan, H. (2007), "Learning style of design students and relationship of academic performance and gender in design education", Journal of Learning and Instruction, Vol. 17 No. 3, pp. 345-359.

Dermitzaki, I., Leondari, A., and Goudas, M. (2009), "Relation between young students' strategic behaviours, domain-specific self-concept, and performance in a problem solving situation", Learning and Instruction, Vol. 19 No. 2, pp. 144-157.

Direito, I., Pereira, A., and Duarte, A. (2012), "Engineering undergraduates' perceptions of soft skills: relations with self-efficacy and learning styles", Procedia-Social and Behavioral Sciences, Vol. No. 55, pp. 843-851.

Duff, A. (2004), "The role of cognitive learning styles in accounting education: developing learning competencies", Journal of Accounting Education, Vol. 22 No. 1, pp. 29-52. 
INTERNATIONAL JOURNAL OF ACADEMIC RESEARCH IN PROGRESSIVE EDUCATION AND DEVELOPMENT

Vol. 8, No. 4, 2019, E-ISSN: 2226-6348 @ 2019 HRMARS

Elahi, T., Fallah, A. P., and Tabataba'i, R. Z. K. (2004), "The relationship between independent/dependent learning styles and progress in learning English", Journal of psychology, Vol. 8 No. 1, pp. 22-36.

Emamipour, S., and Abad, S. E. H. (2007), Cognitive and learning styles, Tehran: Rasesh Publication.

Entwistle, N., and Peterson, E. R. (2004), "Learning styles and approaches to studying", Encyclopedia of Applied Psychology, Vol. 41 No. 6, pp. 537-542.

Farmanbar, R., Zadeh, H. T., Asadpour, M., and Yeganeh, M. (2012), "The relationship between learning styles based on Kolb's theory and academic success among the Nursing and midwifery students", Journal of Guilan University of Medical Sciences, Vol. 22 No. 86, pp. 60-68.

Felder, R. M., and Silverman, L. K. (1988), "Learning and teaching styles in engineering education", International Journal of Engineering education, Vol. 78 No. 7, pp. 674-681.

Fisher, A. (2001). Critical thinking: An introduction, Cambridge: Cambridge University press.

Ghadampour, E., Keshtiaray, N., Hajiabadi, N. H., Ghasr, M. A., and Garavand, H. (2013). "Learning style priorities and its role in critical thinking disposition among nursing school students in mashhad university of medical sciences", Iranian Journal of Medical Education, Vol. 13 No. 8, pp. 652-662.

Ghasemipour, M. (2010), A study on methods for research morale among the high school students of Nourabad Mamasani city in 2009-2010 (Unpublished Master's thesis), University of Allameh Tabatabai, Tehran.

Gheibi, M., Arefi, M., and Danesh, E. (2012), "The relationship between learning styles and selfefficacy of the students in the academic groups", Journal of Applied Psychology, Vol. 6 No. 1, pp. 53-69.

Ghiyasi, A. (2014), "Learning styles for academic success in students of Agriculture and Natural Resources at Tehran University", Journal of Agricultural Education Management, Vol. 6 No. 31, pp. 29-36.

Guven, M., and Kurum, D. (2008), "The relationship between teacher candidates' learning styles and critical thinking dispositions", Elementary Education Online, Vol. 7 No. 1, pp. 53-70.

Gyeong, J. A., and Myung, S. Y. (2008), "Critical thinking and learning styles of nursing students at the baccalaureate nursing program in Korea", Contemporary Nurse, Vol. 29 No. 1, pp. 100-109.

Hainer, E., Fagan, B., Bratt, T., Baker, L., and Arnold, N. (1990), Integrating learning styles and skills in the ESL classroom: an approach to lesson planning, National Clearinghouse for Bilingual, Washington.

Gol, H. A., and Javan, K. H. (2014), "New methods for teaching geography in the first grade of high school based on learning styles", Journal of Geography Teaching, Vol. 109.

Hill, K. Y. (1998), The Effects of Instructional Methodology and Learning Style on Problem Solving (Unpublished doctoral thesis), University of New Orleans, Louisiana.

Largani, H. M., and Seif, A. (2001), "The comparison of learning styles among the students based on gender, level of education and field of study", Journal of Research and Planning in Higher Education, Vol. 7 No. 19, pp. 93-14.

Johnson, E. B. (2002), Contextual teaching and learning: what it is and why it's here to stay. 
INTERNATIONAL JOURNAL OF ACADEMIC RESEARCH IN PROGRESSIVE EDUCATION AND DEVELOPMENT

Vol. 8, No. 4, 2019, E-ISSN: 2226-6348 @ 2019 HRMARS

Thousand Oaks, Calif, Corwin Press.

Khandaghi, M., and Rajaei, M. (2013), "The effect of learning style of the students on their preferred teaching style", Journal of Educational Psychology, Vol. 9 No. 29, pp. 16-32.

Kolb, A. Y., and Kolb, D. A. (2005), "Learning styles and learning spaces: enhancing experiential learning in higher education", Academy of Management Learning \& Education, Vol. 4 No. 2, pp. 193-212.

Kolb, D. A. (1976), The learning style inventory: Technical manual, McBer \& Co, Boston, MA.

Kolb, D. A. (1984), Experiential learning: experience as the source of learning and development, New Jersey, Prentice-Hall.

Kozhevnikov, M. (2007), "Cognitive style in the context of modern psychology; towards an integrated framework of cognitive style", Psychological Bulletin, Vol. 133 No. 3, pp. 464481.

Lithner, J. (2003), "Students mathematical reasoning in university textbook exercises", Educational Studies in Mathematical, Vol. 52 No. 1, pp. 29-55.

Mahbod, M. (2011), The relationship between the parental attachment, metacognition, selfefficacy, and academic success among the high school students (Unpublished Master's thesis), University of Shiraz, Shiraz.

Mao, S. I., and Chang, C. Y. (1998), "Inquiry teaching and its effects on secondary school students learning of earth science concepts", Journal of Geosciences Education, Vol. 46 No. 4, pp. 363-367.

Mehrinejad, A. (2005), A study of the strategy for creating research motivation among the students using the educational curriculum, Tehran, Ministry of Education, Organization for Research and Planning Education.

Miri, M. (2013), The mediating role of the expected research consequences on research morale and perception of professors' supports for research independence, and the students' research motivation (Unpublished Master's thesis), Ferdowsi University, Mashhad.

Mirsoleimani, M. (2011), The level of entitlement of basic sciences curriculum and high school students in basic sciences from research and research morale factors (Unpublished Master's thesis), Marvdasht University, Marvdasht.

Mitchell, A., and Nyland, N. (2005), "Learning styles differ between senior dietetics students and dietetics faculty members", Journal of the American Dietetic Association, Vol. 105 No. 10, pp. 1605-1608.

Mohammedsharifi, Z. (1392), Investigation of research morale and its influencing school factors among elementary school students (Unpublished Master's thesis), Mashhad University, Faculty of Education and Psychology, Mashhad.

Mokhtari, M., Zare'i Zavaraki, E., and Mofidi, F. (2014), "The assessment of communication, thinking and research skills among the students of fifth grade in Tehran city (Academic year 2011-2012)", Journal of New Educational Ideas, Vol. 10 No. 3, pp. 79-102.

Motlagh, M., and Charkhchi, I. (2008), "The barriers and limitations for the development of research thinking in schools as part of the Iranian education system", Journal of Social Science Research, Vol. 2 No. 1, pp. 179-203.

Myers, B. E., and Dyer, J. E. (2006), "The influence of student learning style on critical thinking skill", Journal of Agricultural Education, Vol. 47 No. 1, pp. 43-56. 
Abadi, N. H., Mousavi, S., and Faresan, K. Z. (2013), "The role of critical attitude and cognitive learning style in prediction of academic success in the students at the University of Medical Science", Iranian Journal of Medical Education, Vol. 12 No. 4, pp. 285-296.

Nouhi, E., Salahi, S., and Sabzevari, S. (2014), "The relationship between critical thinking and learning styles in post graduate students of nursing", Journal of the Strides in Development of Medical Education, Vol. 11 No. 2, pp. 179-186.

Papzan, A., Yaghubi, J., Mahin. F. S. H., and Panah, S. M. (2011), "Analysis of procedures and learning styles among the students of Agricultural and Natural Resources based on experiential learning cycle theory, a case study of Razi University", Kermanshah. Journal of Iranian Higher Education, Vol. 3 No. 4, pp. 169-194.

Parsayi, A., Kazemi, S., and Samani, S. (2013), "A comparative study of cognitive learning styles among high school and conservatory students", Journal of Psychological methods and models, Vol. 2, pp. 47-64.

Peppler Barry, U. (2000), The Dakar Framework or Action (1st ed.), Paris, UNESCO.

Pour-Atashi, M., Mohammadi, M. H., and Shaban-Ali Fami, H. (2009), "The recognition of learning styles among the students of agriculture and its effect on the academic success", Journal of Iranian Agricultural Extension and Education Sciences, Vol. 5 No. 1, pp. 37-46.

Jahan, R. H., Saffari, M., Nasab, S. H., Pakpour, A., and Azad, K. M. (2013), "Learning styles among the students of Baqiyatallah University of Medical Sciences in 2012", Journal of Medical Education and Development of Yazd, Vol. 8 No. 1, pp. 52-64.

Rezaei, A., Pour, G. E., and Sharifi, P. H. (2008), "A pattern for creating interest and motivation to study and research: a study on its effectiveness among the middle school students", Journal of Educational Innovations, Vol. 7 No. 25, pp. 151-184.

Ross, G. (2003), "Ethical beliefs, work problem solving strategies and learning styles as mediators of tourism marketing entrepreneurialism", Journal of Vacation Marketing, Vol. 9 No. 2, pp. 119-136.

Rudd, R., Baker, M., and Hoover, T. (2000), "Undergraduate agriculture student learning styles and critical thinking abilities: is there a relationship?", Journal of Agricultural Education, Vol. 41 No. 3, pp. 2-12.

Seif, A. (2010), Modern educational psychology; psychology of learning and teaching, Tehran, Dowran Publications.

Sharp, J. E. (2001), "Teaching Teamwork Communication with Kolb Learning Style Inventory", 31st ASEE/IEEE Frontiers in Education Conference, Reno, NY.

Suleimannejad, A., and Hosseininasab, D. (2012), "Interactive effect of self-regulation strategies and cognitive styles of students on math problem solving performance", Studies of Teaching and Learning, Vol. 8, pp. 81-116.

Suliman, W. A. (2006), "Critical thinking and learning styles of students in conventional and accelerated programs", International Nursing Review, Vol. 53 No. 1, pp. 73-79.

Sunday, A., Babajide, V., and Amusa, J. (2013), "The relationship among teachers' problem solving abilities, students' learning styles and students' academic achievement in physics", Australian Journal of Basic and Applied Sciences, Vol. 7 No. 4, pp. 654-660.

Uchenna, U., and Sunday, A. A. (2011), "The relationship among teachers' problem solving abilities, student's learning styles and students' achievement in biology", International 
Journal of Educational Research and Technology, Vol. 2 No. 1, pp. 82-87.

Weber, K. (2005), "Problem-solving, and learning: the relationship between problem-solving processes and leaning opportunities in the activity of proof construction", Journal of Mathematical Behavior, Vol. 24 No. 3-4, pp. 351-360.

Wessel, J., and Williams, R. (2004), "Critical thinking and learning styles of students in a problembased, Master's entry-level physical therapy program", Physiotherapy Theory and Practice, Vol. 20 No. 2, pp.

79-89.

Woolfolk, A. E. (2004), Educational Psychology, Boston, Allyn and Bacon.

Yogaraj, T. and Selvaraju, R. (2014), "A gender-wise analysis on metacognition and learning styles on problem solving skill of B.Ed trainees", Indian journal of research, Vol. 3 No. 11, pp. 12.

Zanich, M. L. (1991), Kolb learning style inventory; learning style/teaching styles, Indiana University of Pennsylvania, Teaching Excellence Center, Indiana, PA.

Zoghi, M., Brown, T., Williams, B. Roller, L., Jaberzadeh, S. and Palermo, C. (2010), "Learning style preferences of Australian health science students", Journal of Allied Health, Vol. 39 No. 2, pp. 95-103.

Zohrehvand, R. (2006), "The realization of gender-sensitive education in educational planning for general education period", Journal of General Education, Vol. 22 No. 3, pp. 147-174. 